\title{
OBECNÝ POSTUP PŘI TVORBĚ ROZPOČTU ŽELEZNIČNÍCH STAVEB
}

\section{A GENERAL APPROACH TO THE BUDGETING OF RAILWAY STRUCTURES}

\author{
Iveta Střelcová ${ }^{1}$, Eva Pazderková ${ }^{2}$ \\ ${ }^{1}$ Czech Technical University in Prague, Faculty of Civil Engineering, Thákurova 7, Prague 6, 166 29, \\ Czech Republic, iveta.strelcova@fsv.cvut.cz \\ ${ }^{2}$ Ridera Stavebni, V Korytech 1537/10, 10000 Prague, Czech Republic
}

\begin{abstract}
Abstrakt
Článek se zabývá problematikou týkající se postupu tvorby rozpočtu železničních staveb. $V$ úvodu je čtenář seznámen se současnou železniční dopravou a odbornou terminologií, vztahující se na konstrukce železničních staveb. Následuje seznámení se Sborníkem pro opravu a údržby železničních staveb, který je závazný pro stavby financované $z$ veřejného rozpočtu. $V$ další části jsou zpracovány rozdíly v pravidlech rozpočtování u staveb železničních a pozemních. Závěr je věnován nákladové kalkulaci položky, kde je zjištěna nepřesnost v rozsahu ocenění na základě „Sborníku pro údržbu a opravy železniční infrastruktury“.
\end{abstract}

\section{Klíčová slova}

Konstrukce železničních staveb, náklady, cena, rozpočet.

\begin{abstract}
This paper discusses the issue of developing a method for the budgeting of railway constructions. In the introduction, we will concentrate on the description of current railway transportation and we will explain the basic terminology related to the construction of railway infrastructure. In the first part, the paper will give a description and critical evaluation of the book "An anthology for the reconstruction and maintenance of railway constructions", which is obligatory for all constructions that are publicly funded. Then, we will examine the differences in the rules of budgeting between railway structures and building structures. In the last part of this paper, we will calculate one budgetary indicator in order to reveal an inaccuracy in the budgeting of "An anthology for the reconstruction and maintenance of railway constructions".
\end{abstract}

\section{Keywords}

Construction of railway structures, costs, price, budgeting

\section{JEL Classification}

R 42, R 48

DOI: https://doi.org/10.14311/bit.2016.01.04 


\section{Úvod}

Př́spěvek je zaměřen na metodiku rozpočtování u železničních staveb. Úvod je věnován nejen terminologií týkající se konstrukčních prvků u železničních staveb, ale i obecnému postupu při zpracování rozpočtu, ve kterém jsou uvedeny rozdíly v metodice rozpočtování u železničních a pozemních staveb. Na základě jedné případové studie je závěr věnován př́kladu nákladové kalkulace nosné montážní položky, což může být podkladem pro sledování nákladů a tvorbu cen.

Zahraniční literatura zabývající se železniční infrastrukturou je rozsáhlá. Práce zaměřené především na ekonomickou stránku fungování železnic se hlavně věnují obecnějším problémům související s cenovou nákladností údržby a obnovy železniční infrastruktury, jejího plánování nebo roli vlády v otázce investic do železniční sítě. [1], [2], [3]

Počátky železnic $v$ naší zemi jsou datovány počátkem 19. století. Stavba bývalé koněspřežné trati z Linze do Českých Budějovic s úzkým rozchodem $1106 \mathrm{~mm}$ a délkou $129 \mathrm{~km}$ trvala sedm let. Český úsek trati byl uveden do provozu 30. záŕí 1828. [4, s. 13] V průběhu historie se v českých zemích vystř́idalo několik vlastníků železničních drah. $V$ současné době je vlastníkem, stavitelem $i$ provozovatelem většiny železničních tratí v České republice stát, zastoupený státní organizací „Správa železniční dopravní cesty“(SŽDC). Největším národním dopravcem je akciová společnost České dráhy. Mezi další dopravce patří společnosti RegioJet a LeoExpres. Finance pro rozvoj železnice jsou dosaženy zejména z fondů Evropská unie (EU) a také z veřejných rozpočtů prostřednictvím Státního fondu dopravní infrastruktury (SFDI).

V současné době se železniční doprava v České republice se řídí zákonem č. 266/1994 Sb. [5] Podle zákona je dráhou trasa určená $\mathrm{k}$ pohybu drážních vozidel včetně pevných zařizení potřebných pro zajištění bezpečnosti a plynulosti drážní dopravy.

Dráhy jsou rozděleny:

- železniční,

- tramvajové,

- trolejbusové,

- lanové.

Železniční dráhy jsou rozděleny do kategorií podle významu, účelu a technických podmínek stanovených prováděcím nařízením. Kategorie železnic jsou:

- dráha celostátní slouží k mezinárodní a celostátní veřejné železniční dopravě a je jako taková označena,

- dráha regionální sloužící k veřejné železniční dopravě a je zaústěna do celostátní nebo jiné regionální dopravě,

- vlečka, což je dráha samotného provozovatele nebo jiné společnosti, která slouží svým vlastním potřebám a je součástí celostátní, regionální dráhy nebo jiné vlečky

- speciální dráha, která má úlohu zejména k zabezpečení dopravní obslužnosti obce.

Česká republika se řadí mezi země s nejhustší železniční sítí. Její průměrná hustota je 0,12km/km2.

Hustota železnic ve světě [6]

$\begin{array}{ll}\text { Německo } & 0,135 \mathrm{~km} / \mathrm{km} 2 \\ \text { Česká republika } & 0,122 \mathrm{~km} / \mathrm{km} 2 \\ \text { Švýcarsko } & 0,117 \mathrm{~km} / \mathrm{km} 2\end{array}$




$\begin{array}{ll}\text { Belgie } & 0,116 \mathrm{~km} / \mathrm{km} 2 \\ \text { Slovensko } & 0,075 \mathrm{~km} / \mathrm{km} 2 \\ \text { Thai-wan } & 0,070 \mathrm{~km} / \mathrm{km} 2 \\ \text { Velká Británie } & 0,068 \mathrm{~km} / \mathrm{km} 2 \\ \text { Japonsko } & 0,060 \mathrm{~km} / \mathrm{km} 2 \\ \text { USA } & 0,020 \mathrm{~km} / \mathrm{km} 2\end{array}$

\section{Odborná terminologie týkající se konstrukce železniční tratě}

Konstrukce železniční tratě neboli železniční těleso se dělí na:

- železniční svršek

- železniční spodek.

Železniční svršek má funkci nosnou a vodící pro řízení kolejového vozidla. Klasická konstrukce železničního svršku se skládá z kolejnic, upevňovadel, pražců a kolejového lože. [7, s. 143.] Železniční spodek je jednou ze základních částí konstrukce železniční tratě a je tvořen:

- Tělesem železničního spodku,

- stavbami železničního spodku,

- dopravními plochami a komunikacemi,

- drobnými stavbami a zařízením železničního spodku. [8, s. 98]

Klasickou konstrukcí železničního svršku (s kolejnicemi uloženými na přičných pražcích ve štěrkovém loži) Ize považovat kolejový rošt uložený na pražcovém podloží, které tvoří vícevrstvý systém (vrstva štěrku pod pražcem, konstrukční vrstvy tělesa železničního spodku a zemní těleso). Znázorňuje obrázek č.1

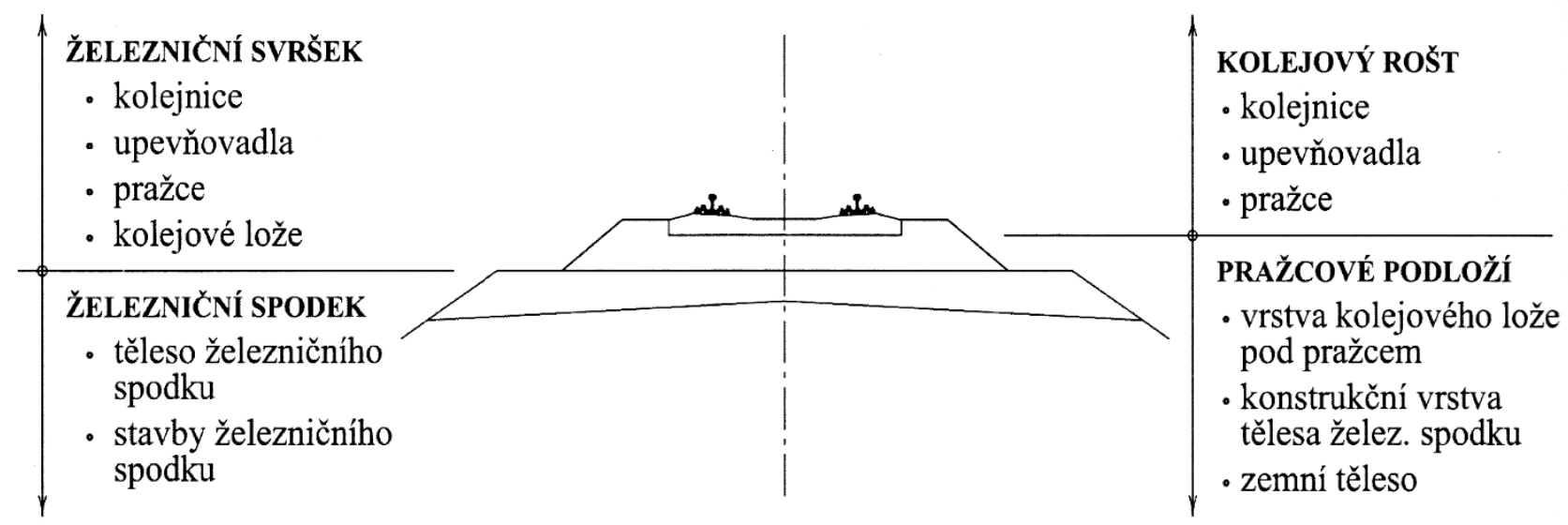

Obrázek 1: Konstrukce železniční trati s klasickým železničním svrškem (zdroj: KREJČlŘíkOVÁ, Hana a Martin LIDMILA. Železniční stavby 1. V Praze: České vysoké učení technické, 2011, str. 98) 


\section{Obecný postup při tvorbě rozpočtu}

Rozpočty na výstavbu železnic podléhají podobným pravidlům jako rozpočty pro pozemní stavby. Je však specifické pro železniční výstavbu, že ve většině veřejných zakázek je investorem SžDC. U staveb financovaných z veřejných prostředků je stanoven sborník, který je závazný pro př́pravu seznamu prací, dodávek a služeb pro opravu a údržbu železniční infrastruktury v rámci zadávání veřejných zakázek ve smyslu zákona č. 137/2006 Sb. (ř́jen 2016 v platnosti nový zákon č. 134/2016) a jeho použití při sestavování soupisu prací podléhá ustanovením dle prováděcí vyhlášky č. 230/2012 Sb. (nahrazeno vyhláškou 169/2016 o stanovení objemu veřejných zakázek na stavební práce a seznamy prací, dodávek a služeb s výkazem výměr). [9, s. 6.]

Pro sestavení soupisu stavebních prací, dodávek a služeb s výkazem výměr se používá Sborník pro údržbu a opravy železniční infrastruktury, který musí být nedílnou součástí zadávací dokumentace pro veřejné zakázky, ale také jako základ nejen pro sestavení kontrolního rozpočtu investora ale i k ocenění slepého rozpočtu (výkazu výměr) dodavatelem. Za vypracování Sborníku stojí společnost ÚRS Praha a.s., která má ve svém software zahrnutou speciální databázi pro dopravní stavby. Je součástí software KROS 4 (software pro oceňování a řízení stavební výroby) a není volně ke stažení.

Na rozdíl, na stránkách Státního fondu dopravní infrastruktury, jsou položky Sborníku volně stažitelné. Tyto položky nesou s sebou pouze jednotkové ceny bez rozboru dle kalkulačního vzorce používaného ve stavebnictví.

Používání Sborníku pro údržbu a opravu železniční infrastruktury se řídi podle pravidel pro použití sborníku, která jsou zveřejněná. [10] Jsou závazná nejen pro všechny organizační jednotky SŽDC, ale i pro projektanty, dodavatele a jiné organizace, které připravují, schvalují a realizují údržbu nebo opravy celostátních a regionálních drah s veřejnou dopravou.

Obsahem pravidel pro aplikaci Sborníku jsou základní informace o podmínkách použití při postupu sestavování soupisu prací, dodávek a služeb v dotčených odvětvích. Jejich cílem je usnadnit orientaci v různých částech Sborníku a definovat pravidla pro hodnocení jednotlivých položek.

Podle pravidel je definována následující terminologie: [11, s. 5]

- Stavbou dráhy je stavba cesty určená k pohybu drážních vozidel a stavba, která rozšiřuje, doplňuje, mění nebo zabezpečuje dráhu bez ohledu, zda je v obvodu dráhy či nikoliv.

- Stavbou na dráze jsou všechny stavby a zařízení v obvodu dráhy, které nejsou stavbou dráhy, bez ohledu na účel, jemuž slouží.

- Součástí dráhy jsou:

- Železniční spodek,

- železniční svršek,

- železniční přejezd,

- stavby a pevná zařízení nutná k ochraně proti nepříznivým vlivům dráhy,

- sdělovací zařízení,

- zabezpečovací zařízení,

- elektrická zařízení,

- pevná zařízení pro měření, údržbu a opravy dráhy a k nim př́slušející budovy,

- pozemky v obvodu dráhy,

- budovy a zařízení určené k organizování, zabezpečení a řízení drážní dopravy.

- Uvedením do provozuschopného stavu se rozumí provedení opravy i s použitím jiných než původních materiálů, dílů, součástí nebo technologií, pokud tím nedojde $\mathrm{k}$ technickému zhodnocení. 
- Údržbou se rozumí soustavná činnost, kterou se zpomaluje fyzické opotřebení a předchází poruchám a odstraňují se drobnější závady.

Ve smyslu interních předpisů správce železniční infrastruktury (DAP SŽDC) platí, že:

- Údržba je soustavná činnost, kterou se udržují kvalitativní parametry, zpomaluje se fyzické opotřebení a odstraňují se jednotlivé závady. Zpravidla se jedná o jednotlivé výkony menšího rozsahu, které musí být odstraněny v krátkém časovém horizontu.

- Oprava je činnost, při které se odstraňují účinky částečného fyzického opotřebení nebo poškození zařizení za účelem uvedení do předchozího nebo provozuschopného stavu. Zpravidla se jedná o provedení plánovaných prací na úseku vyžadující soustředění kapacit.

- Soupis prací, dodávek a služeb stanoví v prímé návaznosti na př́slušnou dokumentaci podrobný popis všech stavebních prací, dodávek či služeb nezbytných $\mathrm{k}$ úplné realizaci předmětu veřejné zakázky, prípadně i popis dalších prací, dodávek a služeb nezbytných $\mathrm{k}$ plnění požadavků zadavatele.

Sborník pro údržbu a opravu železniční infrastruktury je klasifikován dle následujících odvětví:

- Tratové hospodářství,

- sdělovací a zabezpečovací technika,

- energetika a elektrotechnika,

- telekomunikační technika.

\section{Stavebními pracemi se zabývá odvětví tratóoého hospodářství}

V každém odvětví jsou obsaženy dvě části a to:

- Práce a výkony,

- dodávky.

Tyto části jsou zatříděny do kapitol a $\mathrm{k}$ jednotlivým položkám jsou přiřazeny kódy dle číselného třídění.

\section{Číslování a obsah položek}

Položky Sborníku jsou rozpoznány pomocí desetimístného číselného kódu. První dvě až tři místa kódu navazují na oborový třídník OTSKP-žS, který vydává Ministerstvo dopravy pro vypracování zadávací dokumentace staveb pozemních komunikací a železničních staveb.

$\checkmark$ rámci jednotlivých odvětví Sborníku číslování navazuje na existující členění používané v interních předpisech správce železniční infrastruktury. Poslední volná čísla kódu slouží k jednoznačné identifikaci položek tak, aby bylo zabráněno duplicitám v rámci Sborníku. Číselný kód je jednoznačným popisem každé činnosti i dodávky.

Na následujícím obrázku je zobrazena ukázka položek ve Sborníku. 


\begin{tabular}{|c|c|c|c|}
\hline & & & Práce TH \\
\hline položka & popis & m.j. & $\begin{array}{l}\text { cena } \\
\text { - Kč - }\end{array}$ \\
\hline
\end{tabular}

5913

\title{
Železniční přejezdy a komunikace
}

5913005

\author{
Vyčištění železničního přejezdu \\ od nánosu \\ žlábek \\ povrch konstrukce
}

5913005010

$\begin{array}{lr}m & 76,80 \\ m^{2} & 119,00\end{array}$

5913005020

Poznámky:

1. V cenách jsou započteny náklady na vyčištění a uložení výzisku na terén nebo naložení na dopravni prostředek.

5913010

\section{Oprava závěrné zídky}

železničního přejezdu

vyrovnání podkladní vrstvy

5913010010

do $5 \mathrm{~cm}$

přes $5 \mathrm{~cm}$

$\mathrm{m}$

138,00

5913010020

Poznámky:

1. V cenách jsou započteny náklady na demontáž asfaltobetonové vrstvy, závěrné zídky a prípadně podkladního dilu, opravu podkladního betonu, montáž zídky a dilu, doplněni a zhutněni asfaltobetonové vrstvy včetně zajištěni plasticity mezi zídkou a vozovkou.

2. V cenách nejsou obsaženy náklady na prípadné odřiznutí asfaltobetonové vrstvy, demontáž panelů prejezdu a dodávku materiálu.

\section{Obrázek 2: Ukázka tištěné podoby Sborníku (zdroj: SFDI. Sborník pro údržbu a opravy ŽDC, Praha 3/2016. dostupné z: http://www.sfdi.cz/metodiky-a-ceniky/cenove-databaze/)}

Položky pro práce a výkony neobsahují materiál, jedná se o materiál režijní, který se započítává do sazby výrobní režie. Za režijní materiál je považován pomocný a spotřební materiál používaný při opravách a údržbě. Náklad na tento materiál nelze na kalkulační jednici přesně kalkulovat. Jedná se většinou o materiály jako svařovací dávky, dráty, elektrody, technické a topné plyny, pilové listy, brusné a rozbrušovací kotouče, vrtáky, frézy, chladicí kapaliny, barvy a ředidla, štětce, výplňové směsi, tmelicí hmoty, energie, PHM, mazací, konzervační a impregnační prostředky, voda, štítky, drobné propojovací prvky, pomůcky, nástroje a nářadí potřebné $\mathrm{k}$ provedení výkonů, ochranné pracovní pomůcky apod. [9, s. 12-13]

Položky na dodávky materiálů a výrobků jsou omezeny na konkrétní dodávku definovanou popisem a měrnou jednotkou. Jednotkové ceny obsahují pouze pořizovací cenu bez DPH a bez slev. $V$ ceně nejsou zahrnuty náklady na dopravu na skládku na staveniště, jsou součástí mimostaveništní dopravy, která spadá do vedlejších rozpočtových nákladů (VRN).

\section{Použití položek}

Prostor technologické manipulace

Při sestavování rozpočtu není nutné myslet na položky, které berou v úvahu vnitro staveništní přesun materiálu. Náklady na manipulaci s materiálem, jakož i stroje a zařízení jsou zahrnuty $v$ cenách montážních položek Náklady jsou započítány v rámci vymezeného prostoru technologické manipulace okolo místa zabudování.

Náklady na technologickou manipulaci jsou obsaženy v montážních položkách následovně: 
- do 1000 m pro práci na kolejovém spodku i svršku a trakčním vedení,

- do $600 \mathrm{~m}$ pro opravy a instalace větších technologických celků (např. stožáry, transformátory, skříně apod.),

- pokud se práce provádí nepřetržitě po celé délce opravené části, technologický manipulační rozsah je považován za celou délku opravovaného úseku,

- při údržbě a opravách bez manipulace s materiálem nebo manipulace s režijním materiálem není zohledněn žádný prostor pro manipulaci s technologií, náklady jsou zahrnuty v položkách.

V případech, kdy je přepravovaná vzdálenost větší než vzdálenost určená technologickým manipulačním prostorem, jsou zvýšené přepravní náklady posuzovány pomocí samostatných položek. Tyto položky jsou jednou z príloh Pravidel pro použití Sborníku (viz obrázek č.3). V cenách těchto položek jsou zahrnuty náklady na dopravu materiálu ze skladů, skládek výrobce nebo dodavatele, nebo z vlastního portfolia zákazníků na místo technologické manipulace, včetně složení. [12, p. 27]

\begin{tabular}{|c|c|c|c|}
\hline \multirow[b]{2}{*}{ položka } & & & \multirow{2}{*}{$\begin{array}{l}\text { Doprava } \\
\text { cena } \\
\text {-Kč - }\end{array}$} \\
\hline & popis & m.j. & \\
\hline \multicolumn{4}{|c|}{ Doprava dodávek zhotovitele, dodávek objednatele nebo výzisku } \\
\hline 9901000100 & do $10 \mathrm{~km}$ & kus & 108,00 \\
\hline 9901000200 & do $20 \mathrm{~km}$ & kus & 192,00 \\
\hline 9901000300 & do $30 \mathrm{~km}$ & kus & 262,00 \\
\hline 9901000400 & do $40 \mathrm{~km}$ & kus & 338,00 \\
\hline 9901000500 & do 60 km & kus & 490,00 \\
\hline 9901000600 & do $80 \mathrm{~km}$ & kus & 645,00 \\
\hline 9901000700 & do $100 \mathrm{~km}$ & kus & 798,00 \\
\hline 9901000800 & do $150 \mathrm{~km}$ & kus & 1180,00 \\
\hline 9901000900 & do $200 \mathrm{~km}$ & kus & 1560,00 \\
\hline 9901001000 & do $250 \mathrm{~km}$ & kus & 1950,00 \\
\hline 9901001100 & do $300 \mathrm{~km}$ & kus & 2330,00 \\
\hline 9901001200 & do 350 km & kus & 1710,00 \\
\hline 9901009100 & příplatek za každý další 1 km & kus & 7,66 \\
\hline
\end{tabular}

Obrázek 3 Ukázka položek pro ocenění dopravy dodávek nad rámec prostoru technologické manipulace (zdroj: SFDI. Pravidla (metodika) pro použití Sborníku. Vypracoval ÚRS Praha, a.s. Praha 4/2016, str. 27. dostupné z: http://www.sfdi.cz/metodiky-a-ceniky/cenove-databaze/) 


\section{Rozdíly v metodice rozpočtování železničních a pozemních staveb}

Tabulka 1 Rozdíly v pravidlech rozpočtování železniční stavby x pozemní stavby (zdroj: Eva Pazderková, Kalkulace železničních staveb, FSV DP, ČVUT)

\begin{tabular}{|c|c|c|c|}
\hline & & ŽELEZNIČNÍ STAVBY & POZEMNÍ STAVBY \\
\hline 1. & INVESTOR & $\begin{array}{l}\text { Ve většině př́ípadů veřejný } \\
\text { (SŽDC). Výběr dodavatele } \\
\text { podléhá zákonu o zadávání } \\
\text { veřejných zakázek a pro } \\
\text { sestavení soupisu prací je } \\
\text { závazný Sborníku pro úOžl. }\end{array}$ & $\begin{array}{l}\text { Veřejný i neveřejný. U veřejných staveb je při } \\
\text { sestavování rozpočtu možný výběr mezi dvěma } \\
\text { cenovými soustavami společností ÚRS Praha, } \\
\text { a.s. a RTS, a.s. (RTS DATA). }\end{array}$ \\
\hline 2. & ČíSLOVÁNÍ POLOŽEK & Desetimístné & Devítimístné \\
\hline 3. & POLOŽKY & $\begin{array}{l}\text { Rozdělené na čistě montážní } \\
\text { položky a dodávky. }\end{array}$ & $\begin{array}{l}\text { Kromě montážních položek a položek pro } \\
\text { dodávky existují také sloučené položky } \\
\text { obsahující montáž i zabudovávaný materiál. }\end{array}$ \\
\hline 4. & DOPRAVA DODÁVEK & $\begin{array}{l}\text { V montážních položkách je } \\
\text { započítána pouze do } 50 \mathrm{~km} \text { a } \\
\text { do } 0,3 \text { t hmotnosti } \\
\text { přepravovaného materiálu. } \\
\text { Doprava nad rámec tohoto } \\
\text { rozsahu je oceňovaná } \\
\text { samostatnými položkami. }\end{array}$ & Součástí dodávky materiálu. \\
\hline 5. & $\begin{array}{l}\text { VNITROSTAVENIŠTNÍ } \\
\text { PŘESUN MATERIÁLU }\end{array}$ & Součástí montážních položek. & Oceňovaný samostatnou položkou. \\
\hline 6. & KALKULAČNÍ ROZPADY & $\begin{array}{l}\text { Kalkulační rozpady nejsou u } \\
\text { Sborníku pro ÚOžl veřejné. }\end{array}$ & $\begin{array}{l}\text { Kalkulační rozpady jsou u obou Cenových } \\
\text { soustav přístupné. }\end{array}$ \\
\hline 7. & DOPRAVA & $\begin{array}{l}\text { Samostatnými položkami je } \\
\text { oceňována doprava dodávek, } \\
\text { výzisku, suti, vybouraných } \\
\text { hmot, osob a drobné } \\
\text { mechanizace. }\end{array}$ & $\begin{array}{l}\text { Určitým procentem započítáno již v položkách, } \\
\text { nebo Ize individuálně kalkulovat. }\end{array}$ \\
\hline 8. & NALOŽENÍ & $\begin{array}{l}\text { Samostatnými položkami je } \\
\text { oceňováno i naložení sypanin, } \\
\text { kusového materiálu, suti a } \\
\text { vybouraných hmot. }\end{array}$ & $\begin{array}{l}\text { Samostatnými položkami, nebo již zahrnuto } \\
\text { v položkách převážně v oddíle zemní práce. }\end{array}$ \\
\hline
\end{tabular}




\section{UKÁZKA ZPRACOVANÉ NÁKLADOVÉ KALKULACE VYBRANÉ MONTÁŽNÍ NOSNÉ POLOŽKY}

Příklad položky vychází ze zpracovaného rozboru přímých nákladů montážních nosných položek, které byly vybrány z položkového rozpočtu jedné fiktivní stavby.

\section{0 - DopInění KL kamenivem souvisle strojně v koleji [m3]}

Poznámka k položce dle Sborníku pro údržbu a opravy železniční infrastruktury:

- v jednotkové ceně jsou započítány náklady na doplnění kameniva výjimečně ručně vidlemi, nebo souvisle strojně z výsypných vozů případně nakladačem.

- $V$ jednotkové ceně nejsou zahrnuty náklady na dodávku kameniva.

\section{Popis činnosti}

Při čištění kolejového lože dojde přibližně $k 30 \%$ úbytku. Doplnění kameniva se provádí rozprostřením po kolejovém loži a následným podbitím pod pražce. Podbití se provádí současně s úpravou geometrické polohy koleje.

\section{Návrh činnosti}

Doplnění kameniva lze provést dvěma způsoby:

- K rozprostření se použije čtyřnápravový výsypný vůz (označení řady „Faccs 10, 11“), který vyprázdní kamenivo po obou stranách a uvnitř koleje a následně se kamenivo rozprostře pomocí pluhu.

- Nebo Ize využít samovýsypný vagón včetně uložení a rozprostření (označení „Faccpp“).

Navržený způsob uložení a rozprostření kameniva pomocí samovýsypného vagónu je rychlejší, ale pronájem stroje, který je k tomu zapotřebí, je dražší než pronájem vozů a pluhu potřebného k prvé navržené činnosti. $Z$ tohoto důvodu je $v$ nákladové kalkulaci počítáno s první navrženou variantou, tzn. výsypný vưz a pluh.

\section{Nákladová kalkulace položky}

Vychází z fiktivní stavby - úsek dlouhý 1,414 km - nutno rozprostřít $1696 \mathrm{m3}$ kameniva, spotřeba vychází na $1696,8 \mathrm{~m} 3 / 1414 \mathrm{~m}=1,2 \mathrm{~m} 3 / \mathrm{m}$.

- Měrnou jednotkou jsou $\mathrm{m}^{3}$.

Výkony, které jsou udávány v bm budou přepočítány na $\mathrm{m}^{3}$. Pro přepočet je použita skutečná spotřeba kameniva na bm.

- Mechanizace k provedení činnosti:

Výsypný vůz typ „Faccs“ včetně lokomotivy a pluh.

- Doprava kameniva na stavbu:

- nákladními automobily a naložení pomocí bagrů na výsypné vozy,

- dopraveno prímo z kamenolomu po kolejích. 
První varianta dopravy je časově náročnější, ale levnější. V dopravě je nutné zkalkulovat naložení kameniva na výsypné vozy a do pronájmu strojů započítat i náklad na dopravu vozů na staveniště a zpět. V druhé variantě se vozy "dopraví“ na staveniště už při přepravě kameniva. Způsob, jakým by bylo kamenivo na stavbu dodáno, je variabilní podle možností na stavbě (čas, vzdálenost nejbližšího kamenolomu, možnost pronájmu vozů apod.). V kalkulaci je uvažováno s první variantou variantou.

\section{Výpočet - individuální kalkulace položky}

- Celkem je potřeba rozprostřít $1696 \mathrm{~m}^{3}$ kameniva. Přepravní objem vozu Faccs je $38 \mathrm{~m} 3$, tedy 45 výsypných vozů.

- Jedna lokomotiva zvládne utáhnout pouze 10 vozů, předpokládá se pronajmout 5 lokomotiv.

- Pět lokomotiv a 45 vagónů nebude na stavbě najednou. Na rozprostření kameniva se $v$ jeden čas bude podílet pouze jedna lokomotiva se soupravou vozů. Ostatní jsou na cestě nebo při nakládce $v$ kamenolomu.

- Jedna souprava o 10 výsypných vagónech bude rozprostírat $1696 \mathrm{~m} 3 / 5$ lokomotiv = $339 \mathrm{~m} 3$ kameniva. Na $1 \mathrm{mb}$ bude doplněno 1,2 m3 kameniva. To znamená, jedna souprava rozprostre kamenivo $v$ délce $339 \mathrm{~m} 3 / 1,2 \mathrm{~m} 3 / \mathrm{m}=283 \mathrm{bm}$.

- Rozprostření kameniva na 100 bm koleje trvá přibližně 5 minut, to je $5 \mathrm{~min} / 100 \mathrm{~m}=0,05 \mathrm{~min} / \mathrm{m}$. Navíc je před každým rozprostřením nutná příprava vozů, která zabere 15 minut.

- Rozprostření kameniva soupravou bude trvat $=15 \mathrm{~min}+283 \mathrm{~m} * 0,05 \mathrm{~min} / \mathrm{m}=29 \mathrm{~min}$.

- Stanovená $\mathrm{Nh} / \mathrm{MJ}=(29 \mathrm{~min} / 339 \mathrm{m3}) / 60=0,0014 \mathrm{Nh} / \mathrm{m} 3$.

- Na rozprostření se v jeden čas podílí 9 - 10 výsypných vagónů - dále uvažujeme 9.

- Čas potřebný $\mathrm{k}$ výkonu na $\mathrm{MJ}=0,0014 * 9$ vagónů $=0,01288 \mathrm{Nh} / \mathrm{m} 3$.

- V individuální kalkulaci je uvažováno s výkonem pluhu $300 \mathrm{~m} / \mathrm{h}$. Výkon pluhu je pro různá množství doplňovaného kameniva přibližně stejný. Jedná se o individuální kalkulaci fiktivní stavby, kde je počítáno s pluhem, který na $1 \mathrm{bm}$ koleje upraví $1,2 \mathrm{~m} 3$ doplněného kameniva. Doba úpravy profilu $\mathrm{KL}$ pluhem na MJ = 1/(300 m/h*1,2 m3) =0,00278 Nh/m3.

- Pronájem pluhu není počítán na celý den, poněvadž pluh není po celou dobu vytižen. Náklad je nutné zahrnout do sazby za jednu Sh - 60000 Kč/4,71 h = 12 738,85 Kč/Sh.

- Za pluhem jde četa 6 pracovníků, kteří pomocí ručního nářadí provádí očištění kolejnic, upevňovadel a pražců od jemných částí a kamenů. Během jedné pracovní směny, tedy 12 hodin, se zvládne takto očistit $1 \mathrm{~km}$ koleje. Doba čištění $1 \mathrm{~m}$ koleje $\quad=12 \mathrm{~h} / 1000 \mathrm{~m}=0,01200 \mathrm{Nh} / \mathrm{m}$.

- Doba čištění na MJ = 0,012/1,2 m3 =0,01000 Nh/m3.

- Spotřeba lidské práce při očištění na $\mathrm{MJ}=0,01 * 6$ pracovníků $=0,06000 \mathrm{Nh} / \mathrm{m} 3$. 
Na základě zpracovaného rozboru pomocí individuální kalkulace je zjištěno, že náklad na práce prováděné v této položce je závislý více na délce úseku než na množství doplňovaného kameniva. Vzhledem $\mathrm{k}$ tomu, že na bm bývají doplňovány u jednotlivých staveb rozdílné objemy kameniva, nemůže být JC této položky objektivní pro ocenění různých staveb.

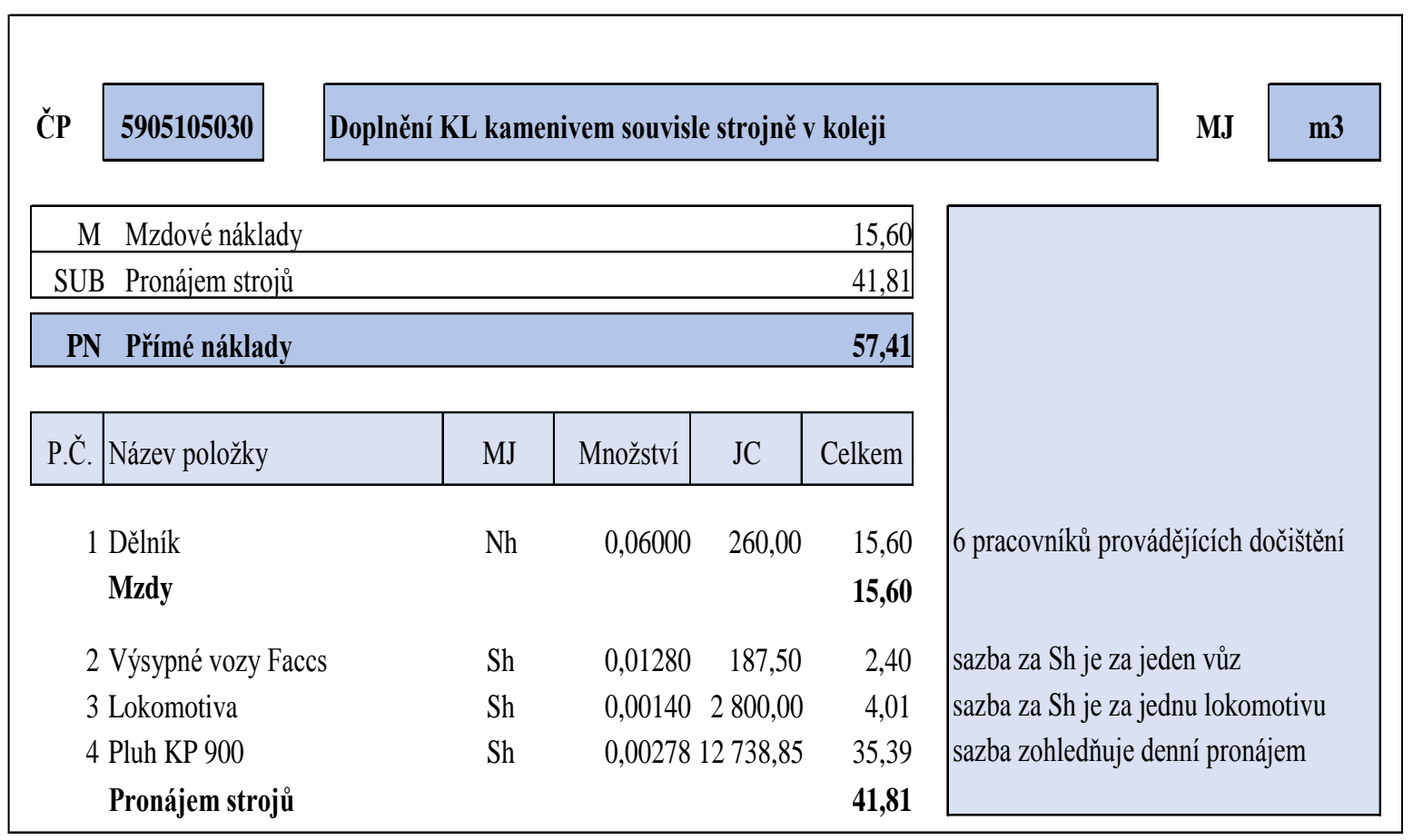

Obrázek 4: Rozbor kalkulace - Doplnění KL kamenivem souvisle strojně v koleji (zdroj: Eva Pazderková, Kalkulace železničních staveb, DP, FSV ČVUT)

Zpracovaným rozborem individuální kalkulace nosné montážní položky je zjištěna nesprávně zvolená měrná jednotka.

\section{Závěr}

Cílem tohoto článku bylo obeznámit čtenáře sterminologií železničních staveb, metodikou rozpočtování podle pravidel Sborníku pro údržbu a opravy železniční infrastruktury a nalézt její rozdíly $\checkmark$ postupu rozpočtování u pozemních staveb.

Dále poukázat na základě zpracované analýzy nákladové kalkulace nosných montážních položek nepřesnosti týkající se především:

- nesprávně zvolené měrné jednotky,

- chybná volba položek pro jednotlivé technologie prací

- nezohledněna rozdílnost nákladů pro malá množství specifikovaného materiálu.

Z tohoto důvodu by měly být ceny ve Sborníku brány pouze orientačně a konečný zákazník by si měl ceny kalkulovat individuálně na základě skutečně provedených prací. 


\section{Reference}

[1] GRIMES A. G., a BARKAN, P.L., CH. Cost-Effectiveness of Railway Infrastructure Renewal Maintenance. Journal of Transportation Engineering, 132/8, 2006. https://doi.org/10.1061/(ASCE)0733947X(2006)132:8(601)

[2] STEWART J., Railway Costs and Planning, Journal of Transport Economics and Policy, 23/1, 1998.

[3] PERKINS, S., The Role of Government in European Railway Investment and Funding. European Conference of Ministers of Transport, China Railway Investment \& Finance Reform Forum, Beijing, China. 20/2005.

[4] SCHREIER, P. Přiběhy z dějin našich drah: kapitoly z historie českých železnic do roku 1918. Praha: Mladá fronta, 2009, str. 13, ISBN 978-80-204-1505-9.

[5] Zákon č. 266/1994 Sb., o drahách ve znění pozdějších předpisů.

[6] OŽANOVÁ, E. Dopravní stavby, 1.Brno: Akademické nakladatelství CERM, 2010. ISBN 978-80-7204-726-0.

[7] PLÁŠEK, O., ZVĚǨINA, P., SVOBODA, R. a MOCKOVČIAK, M. Železniční stavby: železniční spodek a svršek. Brno: Akademické nakladatelství CERM, 2004., str. 143. ISBN 80-214-2621-7.

[8] KREJČIŘíKOVÁ, H. a LIDMILA, M. Železniční stavby 1., Praha: ČVUT, 2011, p. 98, ISBN 978-80-01-04693-7.

[9] SFDI. Pravidla (metodika) pro použití Sborníku. ÚRS Praha, a.s. Praha 4/2016, str. 6 Dostupné z: http://www.sfdi.cz/metodiky-a-ceniky/cenove-databaze/.

[10] SFDI. Pravidla (metodika) pro použití Sborníku. ÚRS Praha, a.s. Praha 4/2016, Dostupné z: http://www.sfdi.cz/metodiky-a-ceniky/cenove-databaze/.

[11] SFDI. Pravidla (metodika) pro použití Sborníku. ÚRS Praha, a.s. Praha 4/2016, str. 5, Dostupné z: http://www.sfdi.cz/metodiky-a-ceniky/cenove-databaze/.

[12] SFDI. Pravidla (metodika) pro použití Sborníku. ÚRS Praha, a.s. Praha 4/2016, str. 12-13, Dostupné z: http://www.sfdi.cz/metodiky-a-ceniky/cenove-databaze/. 